\title{
Araçsal ve İnşacı Yaklaşımlarla Roman Etnik Kimliği
}

\author{
Gizem PARSOVA ${ }^{l}$
}

$\ddot{O} z$

Bu makalede, etnik kimlik kavramı çerçevesinde Türkiye'de yaşamakta olan etnik gruplardan biri olan Romanlar inşacı ve araçsal teorik zeminde tartışılmıştır. Romanlık; ayrımcı/dışlayıcı söylem ve davranış pratikleriyle toplumdaki baskın grup tarafından sürekli yeniden inşa edilmektedir. Bu inşa sürecinin toplumsal arka planında emek piyasasındaki belirli çıar grupları bulunmaktadır. Romanlara yönelik olumsuz kalıp yargıların sürekli yeniden inşası, etnik grubu; formel iş piyasasından uzaklaştırarak enformel iş piyasasında ucuz ve geçici iş gücü olmaya itmektedir. Ucuz ve geçici olarak kullanılabilen Roman işgücü, Roman bireylerin yaşamlarını; nesilden nesile aktarılan yoksulluk olarak sürekli yeniden inşa etmektedir. Kolektif kimlik olarak Roman kimliği dolayısıyla, etnik grubun sahip olduğu sınırlı kaynakların korunmasına yönelik hak talebiyle ilişkilidir. Roman etnik kimliği, yurttaşlık taleplerine yönelik tetiklenen araçsal nitelikli bir kolektif kimliktir; çıkar ortaklığı temelinde geleneğe yapılan vurgu ile duygusal içerik kazanmaktadır. Bireysel kimlik olarak Romanlık, kolektif kimliğe benzer şekilde araçsal niteliğe sahiptir; çıkarlara yönelik birey tarafindan ön plana çıkarılabilmekte veya yok sayılabilmektedir.

Anahtar Kelimeler: Etnik kimlik, Romanlar, İnşa Kuramı, Araçsal Kuram.

\section{Romani Ethnic Identity Through Instrumentalist and Constructivist}

\section{Theoretical Framework}

\begin{abstract}
In this article the concept of ethnic identity has been discussed over Romani as one of the ethnic groups in Turkey, within the theoretical framework of constructivism and instrumentalism. Being a Romani is perpetually reconstructed with discriminatory discourse and treatment by the dominant group in society. In the social background of this reconstruction specific interest groups in labour market are situated. The persistent reconstruction of negative stereotype towards Romani puts them away from the labour market and prompts them to be informal, cheap and temporary labour force. Romani labour force as being a cheap and temporary labour force reconstructs their lifestyle as poverty, passing down from one generation to the other. Therefore, as a collective identity, being Romani is related with the demand for right which aims at the maintenance of the limited sources owned by the ethnic group. Romani collective identity, as a result, has instrumentalist characteristic which is activated by the demand for citizen rights. It gains emotional content with the emphasis on tradition as part of shared benefits. As an individual identity, being a Romani, similar to collective identity, has instrumentalist characteristic; it may be prominent as part of the individual benefits or it may be disregarded.
\end{abstract}

Key Words: Ethnic identity, Romani, Constructivist Theory, Instrumentalist Theory

\footnotetext{
${ }^{1}$ Öğretim Görevlisi, Bülent Ecevit Üniversitesi, Yabancı Diller Yüksekokulu, gizemparsova@gmail.com
}

Bu makale URKUND programı yardımıyla intihale karşı kontrol edilmiştir. 
Giriş

Etnik grup, modern ulus devlet sinırları içerisinde yaşamakta olan insan topluluklarının kültürel çeşitliliğini anlamada kullanılan bir kavramdır. Etnik grupların varlığını kabul etmek, kültürel çeşitliliğin sürekliliği hesaba katıldığında etnik sinırların varlığını da kabul etmeyi gerektirmektedir. Etnik sınırların varlığını düşünmek ise bu sınırlar içerisinde bulunan grup üyelerinin; sahip olduğu kolektif bir etnik kimliğin yanı sıra, somut veya soyut düzeyde sahip olduğu etnisite kavramını da düşünmeyi gerektirir. Kavramlar birbirleriyle ilişkilendirildiğinde; grup üyelerini bir arada tutan bağlar olarak etnik bağlar, gruba has davranış biçimleri olarak etnik davranışlar ve gruba has düşünce yapısı olarak etnik bilinç gibi diğer kavramlar da sorunsallaşmaktadır. Sorunsallaşan bu kavramların, toplumsal gerçeklik zemininde içlerinin nasıl doldurulacağı ise teorik bir tartışma olarak sürmektedir. Etnik grubun nasıl tanımlanması gerektiği, etnik kimliği oluşturan bilincin nasıl ve hangi koşullarda içselleştirildiği, etnik sınırların nasıl muhafaza edildiği ve etnik bağların birey yaşamı üzerinde ne tür etkileri olabileceği gibi birçok soru farklı kuramsal perspektiflerden açıklanmaya çalışılmıştır. Ancak etnik grubun kendi içinde ne ölçüde homojen özellikler taşıdığı, etnik kimliğin ne ölçüde kolektif bir kimlik olduğu ve ne gibi durumlarda aktif hale gelebileceği gibi sorular, etnisite kavramıyla bağlantılı her kavramı muğlâk hale getirmektedir (Yanık 2013: 235).
Araçsal bakış açısı ile konuya yaklaşan Weber'e göre etnik grup; ortak ataya sahip olduğu inancına ve fiziksel görünüm ve/veya gelenekler konusunda benzerliğe sahip; ortak bir dil ve dinin getirisi olan yaşamsal benzerlikler temelinde bir araya gelen insan topluluğudur. Weber, etnik grubu; rasyonel amaçları doğrultusunda bir araya gelmiş, ayrıca özel bir onura sahip olduğuna inanan politik bir topluluk olarak tanımlamaktadır (Weber 1996: 35-36). Bu tanımdan yola çıkılırsa, etnik ayrım; belirli ortak özelliklere sahip olan insan topluluklarının oluşturduğu ayrımdır ve etnik kimlik, grup üyelerinin belirli bir amaca yönelik sahip olduğu kolektif kimliktir. Grup üyeleri arasındaki bağları araçsal olarak nitelendiren bu tanım, etnik gruba üyeliğin duygusal bağlamını yok saymaktadır ve bu nedenle farklı bakış açısına sahip kuramcılar tarafindan eleştirilmektedir.

Bazı kuramc1lar, etnik grubu bir "köken” veya "öz” olarak tanımlamış; bireyin içine doğduğu yerleşik bir kültür ve yaşam biçimi ile ilişkilendirmiştir. Kökene ilişkin bağlar, doğuştan gelen ve yaşamı anlamlandırmamızı sağlayan bağlardır; kan bağları gibi nesilden nesile aktarılarak varlıklarını sürdürmektedir (Geertz 1996: 41-42). Bu görüş, her ne kadar kökensel bağların niteliğinin toplumdan topluma değişeceğini hesaba katsa da; etnik bağların kan bağları gibi kalıtsal ve statik olarak tanımlanması sorun teşkil etmektedir. Sosyal etkileşimin, kökensel bağların oluşumuna etkisinden bahsetmeyen bu kuramsal yaklaşım; etnik grupların zaman içerisinde geçirdiği değişiklikleri veya 
yeni etnik grupların oluşumunu açıklamada yetersiz kalmaktadır (Ellner ve Coughlan 1993: 45-51).

Bazı kuramcılar ise kökenci ve araçsalcı bakış açılarını harmanlamıştır. Etnisite kavramının, insan vücuduyla dışa vurulduğunu iddia eden Fishman'a göre; bu kavramın somut bir şekilde ele alınması gerekmektedir. Çünkü etnisite; dil, fiziksel görünüm ve bedensel pratiklerle bir oluştur. Etnik gruba ait davranış biçimleriyle bir eylemdir ve zihinsel süreçleriyle bir biliştir. Etnisite, gündelik ihtiyaçlara göre yenilenmeye meyillidir ve amaçlıdır; ancak yine de etnsite, bir biliş olarak kökeni anlama ve ebediyetle bağ kurma açısından işlevseldir (Fishman 1996: 63-66). Etnik grubu, kendini sürdüren ve bunun için belirli bir sınırı muhafaza eden özel topluluk olarak tanımlayan Barth ise; etnik sınırların, her zaman açıkça görünen kültürel farklar olmadığını fakat sosyal durumlara ilişkin farklar olabileceğini ileri sürmüştür. $\mathrm{Bu}$ nedenle, etnik sınırların; oluşturulması ve korunmasını, örgütlenme süreçleriyle ilişkilendirmiş ve bu örgütlenme içindeki kültürel özelliklerin zaman içerisinde dönüşebileceğini vurgulamıştır (Barth 1996: 75-77).

Teorik tartışmalar ve bu tartışmalar içerisinde sunulan örnekler, insan toplumlarında etnik grupların ve etnisite kavramının var olduğuna dair ortak bir anlayış geliştirse de; farklı bakış açılarıyla ortaya koyulan bu kavramlar spekülatif özelliğini halen korumaktadır. Günümüz ulus devletleri sınırları içerisinde yer alan etnik grupların; hangi sosyoekonomik ve sosyokültürel bağlamda ortaya çıktığı, varlığını nasıl devam ettirdiği, toplumsal ilişkileri nasıl etkiledikleri ve bu ilişkilerden nasıl etkilendikleri sorularına farklı kuramlar çerçevesinde verilen cevaplar, kavramsal muğlâklığa neden olmaktadır. Bu kavramsal muğlâklığın giderilmesi, etnik grupların; içinde yaşamakta oldukları toplumlarda sosyolojik bakış açısıyla anlaşılmaya çalışılması ile mümkün olacaktır. Sözgelimi, neden bazı etnik grupların toplumun genelinden ve diğer etnik gruplardan çok daha fark edilir boyutlarda ayrıştığını sorgulamak; etnik sınırların nasıl ve hangi dinamiklerle muhafaza edildiğini anlayabilmek açısından önemlidir. Bir toplumun içerisinde yaşamakta olan her bir etnik grubun, kültürel çeşitlilikler olduğu ve toplumdaki hâkim kültürden "farklı" olduğu ön kabulü; her etnik grubun bir “öteki” olduğu düşüncesine teorik zemin oluşturmaktadır. $\mathrm{Bu}$ durumda sorunsallaşması gereken, bu etnik gruplardan bazılarının nasıl "belirgin ötekilere" dönüştüğü ve/veya dönüştürüldüğü ve bu durumun arka planını oluşturan toplumsal süreçlerdir.

Türkiye'de yaşamakta olan etnik gruplar düşünüldügünde, "belirgin öteki” kavramına verilebilecek örneklerden biri, neredeyse her bölgede varlığını hissettiren Romanlardır. Gündelik yaşam alışkanlıkları, fiziksel görünüm konusundaki tercihleri ve kendilerine has davranış biçimlerinin yanı sıra, Romanlar; sosyoekonomik ve sosyokültürel özellikleriyle de toplumsal yaşamda kolayca fark edilecek kadar farklı bir etnik gruptur. Bu farkl1laşma, Roman kültürünün farkl1lığ 1 ve bu farkl11ık temelinde ortaya ç1kan Roman yaşam tarzının belirginleşmesi ola- 
rak değerlendirildiğinde, konuya ilişkin yüzeysel bir açıklama bulmak mümkün görünmektedir. Fakat yapılan araştırmalar, Romanların, kendi dillerini konuşmak ve kendi dini inanışlarını devam ettirmek konusunda hiç de ısrarcı olmadıklarını; tam tersine yaşadıkları coğrafi bölgeye dil ve din konusunda uyum sağladıklarını göstermektedir (Yağlıdere 2007: 133; Kolukırık 2008:149; Çelik ve Şahin 2012:311). Araştırma bulguları, Romanların homojen bir etnik grup olmadığına, aksine heterojen özellikler taşıdıklarına dikkat çekmektedir; Romanlar farklı bölgelerde yaşamakta, farklı diller konuşmakta ve farklı dini inançlarla tanımlanmaktadır. Etnik grubun birçok tanımında vurgulanan ve süreklilik açısından önemli olduğu ifade edilen "ortak dil ve dini inanç"; Romanlar için bir etnik sınır değildir; aksine dil ve dinsel inanış, Romanlar için toplumsal uyum mekanizmasıdır. Bu durumda; Roman kimliğinin, toplumda Roman olmayan bireyler tarafindan kolayca fark edilen belirgin öteki olmaya nasıl devam ettiği cevaplanması gereken bir soru haline gelmektedir.

Romanlar özelinde bu soruya kuramsal cevap veren bazı çalışmalarda, etnik kimliğin bir inşa süreci olarak ele alındığı görülmektedir. İnşacı bakış açısı temelinde, Roman etnik kimliğinin; bir öz olmaktan çok, bir inşa süreci olduğu ve bu kimliğin belirli dışlanma pratikleri ile toplum tarafından sürekli yeniden üretildiği ifade edilmektedir (Illhan ve Frrat 2017: 274). Roman kimliğinin, "biz" ve "öteki” ayrımından beslenen bir "karşı kimlik" olduğu da benzeri şekilde, inşacı görüş temelinde oluşturulmuş bir bakış açısıdır (Ünaldı 2012: 625). Bu bakış açısı, Romanların toplumdan ayrışmasına neden olan olumsuzlama pratiklerine dikkat çekmekte ve bu pratiklerin, Roman etnik kimliğinin belirgin biçimde sürdürülmesine neden olduğunu ortaya koymaktadır. İnşacı bakış açısıyla etnik kimlik kavramını sorunsallaştırmak; inşa sürecinin arka planını ortaya koymayı da gerektirmektedir. Roman etnik kimliğinin yeniden inşası, belirli söylemsel ve davranışsal pratiklerden oluşan bir süreç olarak tanımlanması, bu sürecin; etnik grup sınırları, bu sınırların sürekliliği ve etnik bağlar üzerindeki etkilerini de anlamayı gerektirmektedir. Ayrıca, toplumsal inşaların sürekliliğinin zemininde, belirli toplumsal yapıların muhafaza edilmesi gibi örtük amaçların var olabileceği de sorunsallaşmaktadır. $\mathrm{Bu}$ soruları Romanlar özelinde cevaplamaya çalışan bu derlemenin temel amacı etnik kimlik, etnik yaşam biçimi ve etnik bağlar kavramlarını; arka planını oluşturan toplumsal süreçlerle araçsal ve inşacı yaklaşımlar çerçevesinde anlamaya çalışmaktır.

\section{Roman Etnik Kimliği İnşa Süreci}

\subsection{Romanlığa Yönelik Kalıp Yargılar}

Türkiye'nin neredeyse her bölgesinde yaşamakta olan Romanların kökeninin Hindistan'dan geldiği ifade edilmektedir. Hindistan'dan bilinmeyen bir sebeple ve bilinmeyen bir tarihte göç ettikleri (Yağlidere 2007: 133) adeta bir mit haline gelmiş Romanlar; dünyanın farklı ülkelerinde yaşamaktadır ve yaşadığı toplumlarda sayısal açıdan büyük bir azınlık örneği teşkil etmektedir (Alp 2016: 152). 
Türkiye'de yaşamakta olan Romanlar; Rom, Lom (Poşa) ve Dom olmak üzere üç gruba ayrılmaktadır. Bu gruplar; yaşadıkları coğrafi bölge, dilleri, dinsel inanışları, istihdam kolları ve yaşam tarzları açısından birbirlerinden farkl11ık göstermektedir (Kolukırık 2008: 149). Her ne kadar çeşitlilik gösterse de; Roman kimliği bir etnik kimlik kabul edilmekte; Romanlar sosyolojik olarak bir etnik ayrımı ifade etmektedir (Çelik ve Şahin 2012: 311). Akademik yazında da, bu topluluklara etnik ayrım olarak atıfta bulunmada herhangi bir tartışma söz konusu değildir. Öte yandan, bu etnik gruba atıfta bulunmanın hangi isimle yapılacağı konusunda bir ikilem bulunmaktadır. Bilimsel araştırma yapan bazı akademisyenler "Çingene" adlandırmasını tercih etmekte; bazı akademisyenler ise bu etnik grubu "Roman" olarak adlandırmaktadır. İlgili alan yazında "Çingene" adlandırmasını tercih eden akademisyenler için geçerli sebep; bu adlandırmanın dünya çapında varlığı bulunan bir etnik grubun tamamını ifade etmesidir. "Roman" adlandırması ise, etnik gruba yönelik, popüler temsillerde müzik ve eğlence ile yeniden inşa edilen hoşgörüyü ifade ederken; akademik temsilde itibar ve yurttaşlık talebini inşa etmektedir (Dişli 2016: 114).

Etnik grubun kendini tanımlama biçimleri çoğunlukla "Çingene" değildir; onlar, kendilerini "Roman" olarak tanımlamaktadır (Marsh 2008: 26; Uğurlu ve Duru 2011: 74). "Çingene" adına karşı çıkanlar, sebep olarak; bu ismin hırsılık vb. olumsuz nitelendirmelerle ilişkisini vurgulamaktadır (Bayraktar 2011: 125). Nitekim gündelik dilde varlığını sürdüren bazı deyişler etnik gruba olumsuz özellikler atfederken "Çingene" adının kullanıldığını göstermektedir:

"Çingene ciğer pişirir, yemeden karnını şişirir" (Kaleli 2015: 46),

“Çingene'ye beylik vermişler, önce babasin asmış" (Özafşar 2010: 43),

"Çingene'nin ipini kendisine çektirirler" (Kemal 2005: 51).

"Çingene" adlandırmasının "tehlikeli öteki” inşası ile ilişkisi bulunduğunu ortaya koyan deyişlerin yanı sıra; etnik gruba yönelik olumsuz düşüncelerin, "Çingene" adı üzerinden ifade edildiğini ortaya koyan akademik araştırmalar da bulunmaktadır. Bartın'da yapılmış bir araştırmada, yerel halkın "Çingene" söylemlerinin; ahlaksızlaştırma, kriminalize etme ve bugünden uzaklaştırma temelinde kurulduğu ortaya çıkmıştır (Doğan 2016: 151-155). Ekşi sözlükte "Çingene" başlığı açılarak, katılanların düşüncelerini yazmasının istendiği bir araştırma da, benzer sonuçlar ortaya koymuştur. Araştırmada, katılanların yarısından fazlasının etnik gruba yönelik olumsuz düşünceler paylaştığ1; bu görüşlerin özellikle küfür/hakaret/aşağılama, simgeleştirme ve abartma boyutlarında yoğunlaştı̆̆1 tespit edilmiştir (Alp 2016: 152, 162). "Çingene" kimliğinin, toplumun genelinde olumsuzlanması etnik grubun kendi kimliğini "Roman" olarak tanımlamasında etkili olmuştur. Nitekim "Roman" adının tercih edildiği, grubun örgütlendiği; Edirne Roman Dernekleri Federasyonu, Bursa Roman Derneği ve Dikili Roman Derneği gibi dernek isimlerinden anlaş1maktadır. 
“Tehlikeli öteki” söylemi inşasında kullanıldığı anlaşılan "Çingene" adlandırmasının, etnik grubun kendi üyeleri tarafından reddi, adlandırma meselesini farklı bir boyuta taşımaktadır. "Çingene" kimdir?” sorusunun cevab1, "Roman etnik kimliği” sınırları dışında kalan olarak verildiğinde; "Çingene", Romanların "ötekisidir" ve Roman etnik kimliğinin sınırları dışında kalandır. Bu nedenle, Roman etnik kimliği aç1sından "Çingene değiliz!" söylemi; etnik grubun sınırını çizmenin yanı sıra grubun kendine özgü "onurunu" muhafaza etme işlevine de sahiptir. Öte yandan, toplum tarafindan "Çingene" kimliği üzerine inşa edilen tüm olumsuzluklar öylesine içselleştirilmiştir ki; bu kimlik, Romanlar tarafindan ret edilmektedir (Bayraktar 2011: 125). Dolayısıyla, Roman'ın Çingene etnik kimliğini kabul etmeyişi; aslında Çingene'nin toplum tarafından kabul edilen özelliklerini kabul edişi zeminine oturmaktadır. Baskın grubun ve Romanların, "Çingene" kimliğini karşılıklı kabuller üzerinden ret etmesi ve dışlaması iki tarafın da sınırlarını koruması açısından işlevseldir. Baskın grubun Çingene'ye atfettiği tüm olumsuz özellikler Roman etnik kimliği sınırları açısından belirleyicidir; diğer taraftan baskın grup da kendi kimliğini bu özelliklerin dışında kalan olarak tanımlamaktadır. $\mathrm{Bu}$ durumda, etnik grup; grubun kendi üyeleri tarafindan belirlenen kültürel özelliklerin devam ettirildiği değişime kapalı bir insan topluluğu değildir. Toplumun, herhangi bir etnik gruba ilişkin düşünceleri ve o gruba atfettiği özellikler; grubun kendini tanımlama biçiminde ve kendi sınırlarını çizmesinde önemli bir role sahip olabilmektedir. Etnik kimlik, karşılıklı bir inşa sürecidir ancak Roman etnik kimliğine yönelik toplumun genelinde yerleşik hale gelmiş olumsuz kalıp yargılar ne yazık ki yalnızca "Çingene" adlandırması ile ilişkili değildir. Etnik grup her ne kadar kendi üyeleri ve toplum tarafından "Roman" olarak adlandırılsa da; toplumun etnik gruba atfettiği olumsuz özellikler kalıplaşmış olarak devam etmekte ve Romanlarla toplumun geneli arasındaki açılan sosyal mesafe varlığını sürdürmektedir. Yakın dönemde gerçekleştirilen araştırmalar, Romanların etnik toplum tarafından olumsuzlanan özelliklerine ve bu özellikler nedeniyle toplumdan ayrıştırılmalarına dikkat çekmektedir. Romanlara yönelik sosyal mesafenin ölçüldüğü bir nicel araştırmanın bulgularına göre halk Romanların varlığından rahatsız değildir; ancak onlarla yakın olmayı ve çocuklarının Roman çocuklarıyla aynı ortamda bulunmasını istememektedir (Taylan vd. 2015: 42). Başka bir araştırma; Romanların, toplum tarafindan yeterince tanınmamalarına rağmen; tehlikeli, suç işleyen, temiz olmayan ve küfürbaz gibi olumsuz özelliklerle tanımlanmakta olduğunu göstermektedir (Daşdemir vd. 2016: 30-32). Roman öğrenciler daha küçük yaşlarda okullarda; daha sonra iş yaşamında, komşuluk ilişkilerinde, hatta ibadethanelerde bile ikinci sınıf muamele görmektedir (Diktaş vd. 2016: 1130). Dolayısıyla Romanla-

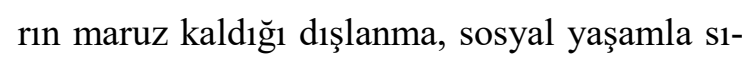
nırlı değildir; dışlanmanın ekonomik, eğitim, hizmetlere erişim, kamusal alanda istihdam ve kültürel faaliyetlere katılım gibi boyutları bulunmaktadır (Genç vd. 2015: 85). Romanlar, yoksunluklarını giderip varlıklı olmaktan ziyade "var olma çabası" gösteren bir etnik gruptur (Uğurlu 2013: 99). 


\section{2. Roman Etnik Kimliği ve Toplumsal De- ğişim}

Etnik kimlik, statik bir öz değildir; toplumsal değişimden etkilenen ve toplumsal değişimi etkileyebilecek bir yapıya sahiptir. Ancak "temsil", etnik kimlik için bu değişimi belirli amaçlar doğrultusunda gizleme çabasına dönüşebilmektedir. Sözgelimi Romanların medya temsilleri, uzun yıllardır neredeyse aynı resmi çizmektedir. Roman mahalleleri, "mutlu ve neşeli” Romanların bir arada yaşadığı mahallelerdir. $\mathrm{Bu}$ mahallelerde yaşayan insanlar genellikle müzisyen veya dansçıdır ve belirli çalışma saatleri olmadığı için yaşam tarzları "rahat ve stresten uzaktır." Çoluk çocuk mahalle sokaklarında bolca zaman geçirir, çocuklarının eğitimini, kendi işsizliklerini ya da parasız oluşlarını dert edinmezler. S1kl1kla kavga eden Romanlar, aslında neşeli insanlardır; kavga anında duydukları bir şarkı bile onların dans etmeye başlaması için yeterlidir. Rengârenk giyinir, saçlarına çiçekler takar ve farklı bir şive ile konuşurlar. Eğlenmeyi sevdikleri için para kazanırken eğlenebilecekleri işlerde çalışmayı tercih ederler. Bazı Romanlar hırsızlık da yapabilir ama zaten böyle durumlar mizahi unsurlara eklemlenmiş olduğu için onlara kızılmaz. Roman kimliği, uzun süredir, "vur patlasın çal oynasın" bir yaşam tarzı ve "göbek atan Romanlarla" temsil edilmektedir. Medya temsilleri, Romanları eğlence unsuru izlekler olarak sunmaya devam ederken bir yandan da onların "suç potansiyeli” taşıdığını aktaran alt mesajlar iletmektedir. $\mathrm{Bu}$ nedenle, TV programlarında toplumu neşelendiren Roman mahalleleri, gerçek ya- şamda suçun etnik kimlikle bağdaştırıldığ " "tekinsiz" yerler olarak düşünülmektedir (Doğan 2016: 152-153).

Öte yandan, yapılan araştırmalar, Roman etnik kimliğinin, gerçek yaşamda, medya temsillerinden oldukça farklı bir görünüm sergilediğini ortaya çıkarmaktadır. Romanların çoğu müzisyen ya da dansçı değildir; aslında müzisyen olanlar, elit kesim Romanlar olarak tanımlanmaktadır (Marsh 2008: 22). Romanların çoğunun oturmaya elverişli olmayan evlerde ikamet ettiklerini, eğitim düzeylerinin oldukça düşük olduğunu, sosyal güvencelerinin olmad1ğını, derin bir yoksulluk içinde olduklarını, kentsel mekanlardan dışlandıklarını, kamusal alanda çok az temsil edildiklerini ve genellikle enformel sektörde çalıştıklarını gösteren araştırmalar bulunmaktadır (Kolukırık 2006: 10; Erdoğan Aras 2009: 88; Koyun ve Çiçekoğlu 2011: 64; Çelik ve Şahin 2012: 324).

Akademik araştırmalar, Romanların toplumdaki dezavantajlı konumunu işaret ederken, medyadaki Roman temsili; renkli, müzik ve eğlence dolu bir Roman dünyasını TV dizileri aracılığıyla toplumla paylaşmaktadır. Çiçek satan, el falı bakan kadınları, darbuka-keman çalan erkekleri ve tüm gün dışarıda oynayan çocukları ile Roman mahalleleri maddi zenginliğe sahip olmasalar bile "neşeli” bir yaşam sürmektedirler. Medyanın Roman mahalleleri, bir etnik grubun; gerçek yaşamda içinde bulunduğu s1nıfsal konum nedeniyle yaşadığı mahrumiyetin perdelenmesi açısından politik işleve sahiptir. Ayrıca, böylesi bir temsil; toplumsal vicdanı rahatlatma açısından da işlevseldir. Medyanın sürekli yeniden inşa ettiği Roman temsili; gerçek 
yaşamda Romanların içinde bulunduğu imkânsızlıkları ve dramı gizlemekte, var olan bir toplumsal sorunu yok saymaya neden olmaktadır.

Roman yaşamının zorluklarını özcülük temelinde değerlendirmek de medya temsillerine benzer bir şekilde bu zorlukları perdeleme ve buradan doğabilecek vicdani rahatsızlıkları hafifletme açısından oldukça etkindir. Romanların sosyoekonomik ve sosyokültürel özelliklerinin, kendi tercihleri doğrultusunda; "etnik gruba özgü yaşayış tarzıyla" ilişkili olduğu iddia edilebilir. Böyle bir iddianın, da medya temsillerine benzer şekilde Roman kimliğine yönelik bir yeniden inşa süreci olduğu düşünülürse; bu inşanın, hangi amaca yönelik yeniden üretildiği sorusunun da cevaplanması gerekmektedir.

Roman etnik kimliğine özgü yaşam tarzının en belirgin özelliklerinden biri, etnik grubun ekonomi piyasasındaki konumudur. Romanların çoğu; enformel sektörde, düzenli olmayan işlerde ve sosyal güvence olmaksızın ça1ışmaktadır (Koyun ve Çiçekoğlu 2011: 64; Çelik ve Şahin 2012: 324). Romanlar, formel emek piyasasından, "hırsız olma ihtimalleri" ve eğitim düzeyleri gerekçe gösterilerek dışlanmakta; ucuz işgücü olarak enformel piyasaya itilmektedir. Romanların emek piyasasında sürekli yeniden üretilen bu dezavantajlı konumu; özellikle orta sınıf işletmelerin piyasa çıkarlarına hizmet etmesi açısından işlevseldir. Özellikle orta sınıf işletmeler için az ücret karşıllı̆ında sosyal güvence sağlanmadan ve kısa süreli olarak kullanılan Roman işgücü, işverenler için önemli bir kaynaktır (Erdoğan Aras 2009: 87-88). Roman işgücünün niteliklerinin piyasa çıkarlarına yönelik sürekli yeniden üretimi, aynı zamanda bir yaşam tarzı olarak Roman yoksulluğunu da yeniden üretmektedir.

Öte yandan, Roman yoksulluğu, çocuk işçiliğinin yaygın kullanımına yol açmakta (Koyun ve Çiçekoğlu 2011: 63; Taylan vd. 2014: 30; Genç vd. 2015: 88; Piirainen 2016: 16) ve yeni nesil Romanların da eğitim olanaklarına zarar vermektedir. Geçimini sağlamaya çalışan Romanların, çocuklarının eğitim giderlerini karşılayamaması ve çocuklarını işgücü olarak kullanmas1; eğitim düzeyi düşük ve yoksul yaşamlarının, nesilden nesile aktarılan bir "etnik yaşam biçimine" dönüşmesine sebep olmaktadır. Sonuç olarak, Romanlar, yoksulluğu ile ayrışmış mahallerde bir arada yaşamaya, "doğru düzgün çalışmadıkları için" dışlanmaya, "çocuklarını çalıştırdıkları" için eleştirilmeye ve "okumadıkları için" cahil olmaya devam etmektedir. Roman etnik kimliğine özgü yaşam tarzında döngüsel hale gelmiş yoksulluk ve eğitim düzeyi düşüklüğü; etnik grup üyelerini toplumsal tabakalaşma hiyerarşisinin de en alt basamağına sabitlemektedir. Roman olmak, böylece bir sınıfsal konumla ve bu konum çerçevesinde ulaşılabilen sınırlı kaynaklarla tanımlı bir kimlik olmaktadır. Bu kimlikle ilişkilendirilen yaşam biçimi ise arka planında gizlenmiş sosyoekonomik ve sosyokültürel süreçlerle sürekli yeniden inşa edilmektedir. Romanlar tarafindan yoksulluk içselleştirilmiş; etnik grubun karakteristik bir özelliği haline gelmiştir (Kolukırık 2006: 19). 


\section{Roman Etnik Kimliğinin Araçsallığı}

\section{Bireysel Kimlik Olarak Romanlık}

Romanlara ilişkin yapılan bazı araştırmalar, Roman bireylerden bazılarının; karma ve orta sınıf mahallelerde yaşadıklarını, Roman kültürüne hiç yakın hissetmediklerini ve en önemlisi kendilerini Roman olarak tanımlamadıklarını göstermektedir (Taylan vd. 2015: 31; Piirainen 2016: 35). Bazı araştırmalar, benzeri biçimde, eğitim düzeyi yüksek ve kamuda çalışan Romanların etnik kimliğini gizlediğini tespit etmiştir (Kolukırık 2008: 151). Bu araştırmalar, etnik bağların; bireyler açısından belirli koşullarda değerini yitirebileceğini işaret etmektedir. Romanlar özelinde etnik bağlarda kopma yaşanmasının, sosyoekonomik düzeyde yükselme ile ilişkili olduğu görülmektedir. Bireyin, formel istihdamla ve gelir artışı ile değişen yaşamı, ayrışmış yoksulluk içerisinde yaşayan Roman mahallesinden ayrılışını beraberinde getirmektedir. Roman yaşamından uzaklaşan bireyin, kamusal kabul sağlamak amacıyla olumsuz içerimleri bulunan ve belirli bir sınıfsal konumla ilişkili olan etnik kimliğini yok sayma davranışına yönelmesi oldukça akla yatkın görünmektedir. Bu durumda, sınıfsal konum değişikliğinin bireyin etnik bağlarını yok saymasına neden olabileceği iddia edilebilir.

Etnik kimliğin gizlenmesi ya da yok sayılması davranışının bir başka kaynağı da sosyal dışlanma korkusu yaşanmasıdır. Bazı Roman çocukları, eğitim gördükleri okullarda kimliklerini gizlemektedir. Bu davranışın kaynağının Roman çocukların hissettiği sosyal dışlanma olduğu düşünülmektedir (Genç vd. 2015: 94). Nitekim "Romanlara yönelik ön yargılar"
Roman çocuklarının eğitim sürecinde karşılaştıkları sorunlardan biri olarak tanımlanmaktadır (Kolukırık 2013: 12). Dolayısıyla, bireyler için etnik kimlik, içinde bulundukları sosyoekonomik ve sosyokültürel çevreye ayak uydurabilmek amacıyla, yok sayılabilmekte ya da gizlenebilmektedir.

Öte yandan, Türkiye'de yaşamakta olan Romanların bazılarının; sosyoekonomik koşullarında yükselme olduğu koşullarda bile etnik kimliğinden vazgeçmemesi; böyle bir iddiayı geçersiz hale getirmektedir. Sözgelimi Kibariye, eğlence sektöründe başarılı bir isim haline gelmiş, yoksul Roman yaşamından kurtulmuş fakat Roman kimliğinden vazgeçmemiş bir isimdir. Roman etnik kimliğinin içselleştirilmesine ilişkin bu iki karşıt durum birlikte değerlendirildiğinde; sınıfsal konum yükselmesinin bireyin etnik bağları üzerinde etkisi olduğunu iddia etmek zorlaşmaktadır. Bu noktada etnik bağların duygusal içeriğini tartışmaya dâhil etmek de zor görünmektedir. Araçsalcı yaklaşım çevresinde, bireylerin etnik bağlarının derinliğini ve yoğunluğunu değiştiren dinamiğin, rasyonel amaçlar olduğunu kabul etmek ise; etnik kimliğin yok sayıldığı ve daha ön plana çıkarıldığı bu iki zıt duruma teorik bir açıklama getirmektedir. Nitekim iki örnekte de birey etnik bağlarını içselleştirme konusunda rasyonel tercih yapmaktadır. Kamuda çalışmaya başlayan birey için rasyonel davranış etnik kimliğini yok saymaktı; toplumsal kabul görmek amaciyla bu davranışa yönelmektedir. Kibariye ise benzer bir rasyonel davranışla tam tersi bir davranışa yönelmekte, etnik kimliğini ön plana çıkarmaktadır. Müzisyen kimliğine eklemlediği etnik 
kimliği, etnik grubundan beklediği piyasa desteğiyle ilişkilidir. Dolayısıyla, bireylerin etnik bağları, araçsal hale gelebilir ve bireyler bu bağların niteliği konusunda rasyonel tercihlerde bulunabilirler.

\section{Kolektif Kimlik Olarak Romanlık}

Etnik kimliği kolektif bir kimlik olarak kavramsallaştırmak; etnik grup üyelerinin belirli ortak paydalarda uzlaştıklarını ve bu uzlaşımın aralarında bir bağ oluşturduğunu varsaymayı da beraberinde getirmektedir. Aileyi bir arada tutan bağlara benzeyen fakat biyolojik temeli olmayan bu bağlar "biz olma duygusu" ile ilişkilendirildiğinde ise etnik bağların duygusal nitelikli olduğu sonucuna ulaşmak da mümkündür. Etnik bağların, yukarıda tartışılan bireysel niteliği ise bu bağların temelinde olduğu düşünülen duygusallığı sorgulamayı gerektirmektedir.

Etnik kimliğin kolektif boyutu, etnik gruba ait örgütlenme biçimlerinde ortaya çıkmaktadır. Politik talepler doğrultusunda bir "biz" söylemi oluşturmak etnik gruba aidiyeti vurgulamak açısından bağları güçlendiricidir. Ancak gruba ait talepler söz konusu olduğunda yapılan ortak yaşanmışlık ve gelenek vurgusuyla harekete geçirilen duygusallık yine araçsal niteliktedir. Etnik grubu bir araya getirebilmek ve örgütleyebilmek amaciyla harekete geçirilen "biz duygusu" etnik bağlarda güçlenme sağlayan bir dinamiktir. Türkiye Romanlarının kolektif kimliğini güçlendiren ve Romanları yurttaşlık talebi doğrultusunda politikleştirerek "biz" söylemi oluşturmalarına hız kazandıran gelişmeler aşağıda özetlenmiştir.

\subsection{Yasal Düzenlemeler ve Dernekleşme}

Türkiye Romanları özelinde kolektif kimliği güçlendiren etnik örgütlenme 2000'li yıllarda gündeme gelmiştir. Romanların, politik talep doğrultusunda oluşturduğu örgütlenmenin önünü açan gelişmelerin başında dernekleşme önündeki yasal engellerin kalkması gelmektedir. 2004 yılına kadar yürürlükte kalan 6 Ekim 1983 tarihli Dernekler Kanunu'nun 5. Maddesinde; derneklerin "irk, din, mezhep, kültür veya dil farklılığına dayanan" isimlerin konulamayacağı, derneklerin bu konularda faaliyet yürütemeyeceği yer almaktaydı. Derneklerin adında etnik grup isimlerinin kullanılması idare ve yargı kararlarıyla engellenmişti (www.radikal.com.tr). 2004 yılında, yürürlüğe giren 5253 sayılı Dernekler Kanunu ile bu madde yürürlükten kalkmış ve etnik grupların, isimlerini kullanarak dernekleşmeleri yasal açıdan mümkün hale gelmiştir (www.dernekler.gov.tr). Nitekim Nisan 2004'te kurulan Edirne Roman Kültürünü Araştırma, Geliştirme, Yardımlaşma ve Dayanışma Derneği'nin kurulması, yasal engellerin kalkması ile Roman örgütlenmesinin başladığını işaret etmektedir. Bu derneğin, Avrupa Roman Hakları Merkezi ve Helsinki Yurttaşlar Derneği ile birlikte 2005-2008 yılları arasında gerçekleştirdiği “Türkiye'de Roman Haklarının Geliştirilmesi” projesi, Roman etnik örgütlenmesinin yasal engeller kalktıktan sonra, yurttaşlık talebi doğrultusunda güçlenmesini hedefleyen ilk çalışmalar arasında yer almıştır. 2006 y1lında kurulan ve 11 Roman derneğini kapsayan 
Roman Dernekleri Federasyonu da Edirne Roman Kültürünü Araştırma, Geliştirme, Yardımlaşma ve Dayanışma Derneği'nin öncülügü ile kurulmuştur (Ilikk 2016: 13). Dolayısıyla Roman etnik örgütlenmesinin 2004 yılında yürürlüğe giren 5253 sayılı Dernekler Kanunu ile hız kazanmaya başladığı söylenebilmektedir.

\subsection{Roman Açılımı Süreci}

Türkiye Romanlarının etnik örgütlenmesine ve Roman sivil toplum kuruluşlarının gelişimine hız kazandıran en önemli dinamik olan Roman Açılımı 2009 yılında dönemin başbakanı olan Sn. Recep Tayyip Erdoğan tarafından Roman yurttaşların sorunlarına ilişkin yapılan toplantılar ve açıklamalarla başlamıştır. Ankara'daki Roman sivil toplum kuruluşları ile yapılan toplantılarla başlayan bu süreç (İlik 2016: 8), Sn. Recep Tayyip Erdoğan'ın katılımı ve Türkiye'nin dört bir yanından gelen Roman yurttaşların 14 Mart 2010'da İstanbul'da gerçekleşen buluşması ile Roman sorunlarına yönelik çözüm arayışlarında bir dönüm noktası olmuştur. Başbakan Recep Tayyip Erdoğan'ın bu buluşmada Romanların sorunlarına çözüm getireceğini ifade etmesi, etnik gruba; sevgi ve hoşgörü temelinde yaklaşması Roman yurttaşlar için çok büyük bir öneme sahiptir. Bu buluşmada ayrıca Roman yurttaşların barınma sorunlarına getirilen toplu konut çözümünün bizzat başbakan Recep Tayyip Erdoğan tarafından müjdelenmesi büyük bir sevinç ve coşku ile karş1lanmıştır (www.radikal.com.tr).
Roman Açılımı, Türkiye'nin farklı illerinde faaliyet göstermekte olan Roman derneklerinin işleyişi için de bir dönüm noktası olmuştur. 2013 y1lında Türkiye'nin çeşitli illerinden 6 Roman Federasyonu ve 95 Roman derneğinin katılımı ile Kocaeli'de gerçekleşen toplantıda Türkiye Romanlar Federasyonu kurulmasının kararı alınmış ve federasyon başkanlığına Kocaeli Roman Dernekleri Federasyonu Başkanı olan Ahmet Çokyaşar seçilmiştir (www.iha.com.tr). Roman etnik örgütlenmesini Kocaeli' de merkezi hale getiren bu gelişme, Roman Açılımı sürecinde atılan önemli adımlardan biridir. Türkiye Roman Dernekleri Federasyonu, Kocaeli Belediyesi ile 18 Nisan 2013'de gerçekleştirdiği "Roman Gruplarının Sosyolojik Görünümü ve Gelecek Senaryoları Çalıştayı" ile Roman yurttaşların sorun alanlarını belirleyen bir çalışma yürütmüştür. $\mathrm{Bu}$ çalışmada ortaya konan eylem ve strateji planı Kocaeli ili merkezinde yapılmış bir pilot uygulama olmakla beraber, bu sorunların çözümüne yönelik olası bir ulusal bir eylem planı ortaya koymayı hedeflemiş olması açısından oldukça önemlidir (Koukırık 2013: 6-7).

Roman Açılımı Süreci; kalkınma planları, bakanlıkların çalışma raporları ve Romanların Yoğun Olarak Yaşadıkları Yerlerde Sosyal İçermenin Desteklenmesi Operasyonu (SİROMA) Projesi gibi hukuksal kazanım ve uygulamaların da önünü açmıştır (İlik 2016: 9). SIROMA Projesi, 9 Kasım 2015'te uygulanmaya başlamış; Dış İlişkiler ve AB Genel Müdürlüğü, Aile ve Sosyal Politikalar Bakanlığg ve Milli Eğitim Bakanlığı Müdürlüğü tarafından 
ortaklaşa yürütülen, Avrupa Birliği Katılım Öncesi Mali Yardım Aracı (IPA) İnsan Kaynaklarının Geliştirilmesi Operasyonel Programı kapsamında hazırlanan bir proje olarak tanımlanmaktadır. Bu proje; pilot il olarak seçilen 12 ilde yaşayan Roman yurttaşlara yönelik kamu hizmetlerinin yükseltilmesi, Roman vatandaşların temel kamu hizmetlerine erişimini ve talebini artırma ve istihdam edebilirliğini artırma hedefiyle çalışmaktadır (http://disab.sag$\underline{\text { lik.gov.tr). }}$

Roman yurttaşların; eğitim, barınma, istihdam, sağlık, sosyal hizmet ve sosyal yardım sorunlarının çözümüne yönelik gerçekleştirilen önemli çalışmalardan biri de Aile ve Sosyal Politikalar Bakanlığı'nın hazırladığı ve 27.04.2016'da Yüksek Planlama Kurulu tarafından onaylanan Roman Vatandaşlara Yönelik Strateji Belgesi (2016-2021) ve 1. Aşama Eylem Planı (2016-2021)'dır. Roman yurttaşların temel sorunlarının tanımlandığı ve bu sorunların çözümüne yönelik stratejik hedeflerin ortaya konulduğu Aile ve Sosyal Politikalar Bakanlığı'nın Strateji Belgesi ve Eylem Planı; ilgili kamu kuruluşları ve sivil toplum kuruluşlarının desteğiyle Roman yurttaşların yaşamlarını iyileştirmeyi hedeflemektedir (www.aile.gov.tr).

Roman Açılımı olarak tanımlanan ve 2009 yılında başbakan olan Sn. Recep Tayyip Erdoğan tarafından başlatılan süreç, etnik grupların toplumdaki var olma çabasına ilişkin devlet politikalarının önemini vurgulamaktadır. Özellikle Romanlar gibi toplumun genelinden "belirgin öteki" olarak ayrışan ve sosyal dışlanmaya maruz kalan bir etnik grup için şüphesiz devletin koruyucu ve kollayıcı elini hissetmek çok önemlidir. Sn. Recep Tayyip Erdoğan'ın Roman yurttaşlara yaklaşımının sevgi ve hoşgörü temelinde bizzat kendi tarafından ifadesi; Roman etnik kimliğine yönelik toplumun genelinde yerleşik hale geldiği düşünülen olumsuz kalıp yargıların yok edilebilmesi açısından da örnek davranış biçimi olarak sembolik hale gelmiştir.

\subsection{Kentsel Dönüşüm}

Roman etnik örgütlenmesine hız kazandıran bir diğer faktör ise Türkiye'de birçok ilde yaşanan kentsel dönüşüm sürecidir (Akgül 2010: 216). Türkiye'de 2000'li yıllardan itibaren ortaya çıkan kentsel dönüşüm uygulamaları, kentsel bölgeleri daha çağdaş bir görünüme kavuşturmak, üretim merkezlerinin işlerliğini artırmak ve konut sorununu çözmek amaciyla başlatılmıştır. Kent merkezlerinde bulunan gecekonduların yıkılması ve merkezin yeniden yapılandırılarak orta ve üst sınıfın kullanımına uygun hale getirilmesi yönünde yapılan çalışmalar, Romanlar da dâhil olmak üzere kent merkezlerinde yaşamakta olan alt sınıfın kent merkezinden taşınmak zorunda kalmasına neden olmuştur (Uğurlu 2013: 76). TOKİ tarafindan pek çok ilde son yıllarda başlatılan kentsel dönüşüm sürecine karşı çıkan Romanlar tarafından "yerinden edilme ve dışarıda bırakılma" söylemi Roman etnik örgütlenmesini tetiklemiştir. Bu söylem, politik amaç birliği yapan Romanların, geleneksel yaşam biçimine yapılan vurgu ile duygusal boyut kazanmış; kentsel dönüşüm sürecinde, evlerini boşaltmak zorunda bırakılacak Romanlar için; bir mücadele alanı başlamıştır. 
Kentsel dönüşüme karşı çıkan Romanlar, bu süreç sonunda yeni yapılacak apartman dairelerini kiralamanın veya satın almanın zorluklarının yanı sıra; bu konutların kendi kültürlerine ve yaşam biçimlerine uygun olmadığını ifade etmiştir (Uğurlu ve Duru 2011: 76). Kentsel dönüşüme karşı çıkan İstanbul Sulukule Romanları, örgütlenerek bir platform oluşturmuş; "mahalleyi kurtarmak" amacıyla hukuksal mücadele yürütülmüştür (Uysal 2012: 18). Dolayısıyla, etnik örgütlenme politik talepler doğrultusunda oluşturulurken etnik bağların güçlendirilmesi ortak mücadele açısından önem taşımaktadır. Politik amaç ortaklığı etnik bağları tetiklemekte; gruba özgü kültür ve yaşam tarzının vurgulanması ile duygusal zemine taşınmaktadır.

Kentsel dönüşüm süreci, Romanların bir bölümü için etnik örgütlenmeyi tetikleyen ve etnik duyguları harekete geçiren bir unsurdur. Öte yandan, kentsel dönüşüm, Romanları kent mekânından uzaklaştırmıştır. Kent merkezlerine yeni yapılan apartman dairelerini satın almanın veya kiralamanın, maddi açıdan çok zor ve hatta imkânsız olması nedeniyle Romanlar; oturdukları mahallelerden taşınarak kent merkezine uzak gecekondu mahallelerine sığınmak zorunda kalmıştır (Uğurlu ve Duru 2011: 76; Uğurlu 2013: 100). Roman mahallelerinin kent merkezlerinden uzaklaşması, toplumdan daha da ayrışmalarına sebep olmuş ve Romanları yalnızlaştırmıştır. Ayrıca böyle bir ayrışma, Romanları kent merkezine uzak, varoş mahallelere, sınırlı kaynaklar içerisine hapsederek Romanların kendine özgü yaşam tarzını yeniden inşa eden bir dinamik haline gelmiştir.
Kentsel dönüşüm, Romanlar için yalnızca barınma sorununa değil; kent merkezlerinde atık kâğıt ve plastik toplanmasının Çevre ve Şehircilik Bakanlığı tarafından yasaklanması ile aynı zamanda geçim sorununa da neden olmuştur. Edirne Roman Eğitim Gönüllüleri Derneği Başkanı'nın 27.01.2016 tarihli basın açıklamasında sokaklarda çöp toplamanın Avrupa Birliği standartlarına uygun ve sağlıklı bir şekilde, lisanslı firmalar tarafından gerçekleştirilmesine yönelik Çevre ve Şehircilik Bakanlığ kararı sert bir şekilde eleştirilmektedir:

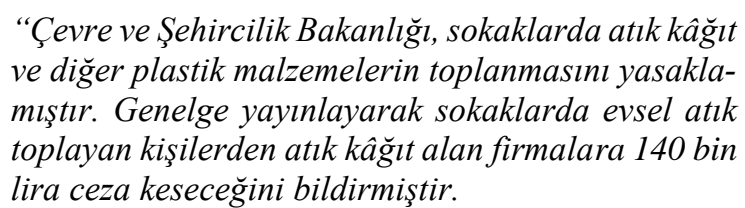
Çevre ve Şehircilik Bakanlığ bu almış olduğu karar ile Türkiye gerçeğini görmezden gelmektedir. Türkiye Cumhuriyeti, sosyal devlet anlaylşı içinde bu soruna çare bulmalı mağduriyet ortadan kaldırılmalıdir. Aksi takdirde bu sektörden geçimini sağlayan milyonlarca insanı isssiz ve aşsız birakacak, sosyal sorunlar daha da artacaktur.

Insanların geleneksel işs sahalarını yasaklayarak onları bu kazanç kapılarından uzaklaş̧ırmak, toplumsal barışı bozucu sonuçlara yol açabilir. Geri dönüşüm uygulamalarında devletin düzenlemeleri yasaklayıcı değil, sağllklllaştırmayı hedef alması gerekmektedir. Akla ve düşünceye uygun yasalar toplumsal birlikteliği pekişstireceğini görmemiz gerekli" (Şall 2016).

Romanların, kentsel dönüşüm ile başlayan barınma sorunlarına geçim kaynağı sorunlarının da eklendiğini gösteren bu basın açıklamas1, etnik örgütlenmenin; ekonomik sorunlara çözüm arayışında ortak çıkar temelinde tetiklendiğini ortaya koyan başka bir örnektir. Etnik grubun "hak arama söylemi” geleneksel geçim kaynağı olarak tanımladıkları atık toplama faaliyetlerini engelleyen politikalara yönelik bir 
karş1 söylemdir. Bu karş1 söylem oluşturulurken de Romanların, bir meslek kolunu, barınma biçimlerindeki vurguya benzer şekilde, etnik grubun yaşam biçimi ile ilişkilendirdiği görülmektedir; etnik bağların duygusal bileşenini politik amaç tetiklemiştir. Yaşam tarzının gelenekselliğine yapılan vurgu, etnik grubun, ortak geçmiş ve yaşanmışlık paydasında birleşimini sağlayan bir tutkal işlevine sahiptir. Duygulara dayanmaktadır; ancak duygusallık politik bir amaca yönelik araçsal bir duygusallıktır. Duygular; etnik grup üyelerinin, ortak bir soruna çözüm bulma amacıyla etnik bilince yapılan gönderme ile harekete geçmektedir.

Edirne Roman Eğitim Gönüllüleri Derneği'nin basın açıklamasında, geleneksel geçim kaynağı olarak sokak atığı toplama faaliyetinin gösterilmesi ve bu faaliyetin gerçekleştirilebilmesi için yapılan sosyal devlet vurgusu, etnik kimlik ve yurttaş kimliğinin birleştiği bir zemin oluşturmaktadır. Öte yandan, dernek başkanının, formel istihdam talebi olmaksızın enformel geçim kaynaklarını geleneksel geçim kaynağı olarak sahiplenmesi ve bu kaynağın kaybı ile ilgili endişelerini dile getirmesi; Romanlar özelinde yapılanmış yurttaşlık bilincinin eksikliğine dikkat çekmekte ve farklı etnik gruplara özgü farklı yurttaşlık bilinçleri olabileceğini düşündürmektedir. Etnik grup üyelerinin yurttaşl1k bilincinin eksik yapılanması ise etnik grubun sahip olduğu sınırlı kaynaklarla ilişkilendirilebilir. Bu kaynaklar, etnik grubun üyelerinin, toplumsal tabakalaşma hiyerarşisindeki konumu ile ilişkilidir. Bu hiyerarşinin en alt basamağında bulunan Romanlar için "yurttaşlık", ulaşabildikleri kaynak ve firsatların sınırlılığ çerçevesinde anlamlandırılmaktadır. Dolayısıyla Romanlar, tabakalaşma sonucu kurulan vatandaşlar hiyerarşisinin (Güllüpınar 2012: 109) de en alt basamağında bulunmaktadır. Diğer bir deyişle, etnik grup örgütlenmesinin temel zeminini oluşturan vatandaşlık hakları talebi; grubun ait olduğu toplumsal tabakaya göre şekillenen bir yaşam tarzını içselleştirmesine ve yurttaşlığın da bu çerçevede algılanmasına neden olabilmektedir.

Öte yandan kentsel dönüşümü yakın dönemde tecrübe etmiş bir il olan Kocaeli Romanlarını (Uğurlu 2013: 95-98) işgücü piyasasına dâhil etme hedefli 2017 'de başlatılan "Roman İstihdam ve Mesleki Danışman Ağı” projesi (www.habertürk.com.tr.) etnik gruba ait yurttaşlık bilincinin grup üyelerinin sınıfsal konumu ile sınırlı olmadığını ispatlamaktadır. Edirne Eğitim Gönüllüleri Derneği Başkanının atık toplama faaliyetinin devamı talebine karşıl1k, Kocaeli merkezli Türkiye Roman Dernekleri Federasyonu'nun başkanı Ahmet Çokyaşar'ın Roman istihdamı sorununa Sosyal Güvenlik ve Çalışma Bakanlığı, Milli Eğitim Bakanlığı ve Kocaeli Belediyesi gibi kuruluşların katkısı ile çözüm getirmeye çalışan projesi etnik örgütlenmenin niteliği konusunda düşündürücüdür. İstihdam sorununu farklı açılardan tanımlayan ve çözüm arayan bu iki dernek, Roman etnik örgütlenmesindeki yetersizliğe ve sivil toplum kuruluşları arasındaki iletişimsizliğe dikkat çekmektedir. Türkiye Romanlarının yurttaşlık talebine yönelik oluşturduğu etnik örgütlenme; sorun ve çözüm konusunda amaç birliği sağlayamaması nedeniyle parçalı ve Edirne 
örneğinde görüldügü gibi yurttaşlık talebi eksik yapılanmış bir örgütlenmedir.

\section{Sonuç ve Tartışma}

Etnik kimlik kavramını, Romanlar özelinde tartışan bu makalede, Roman etnik kimliğinin; verili bir öz olmaktan öte toplumsal bir inşa olduğu sonucuna varmak mümkündür. Toplumdaki baskın grubun Romanlara yönelik ayrımcı ve dışlayıcı söylem ve pratikleri; etnik grubu "belirgin ve tehlikeli öteki olarak" konumlandirmaktadır.

Roman etnik kimliğinin olumsuz kalıp yargılarla sürekli yeniden inşa edilmesi, Roman bireylerin sosyoekonomik ve sosyokültürel özellikleri çerçevesinde erişebildiği kaynakların sınırlanmasına yol açmaktadır. Sınırlı kaynaklara erişim ise Roman bireylerin yoksulluk ve eğitimsizlikle örülü ayrışmış yaşamlarının döngüsel olarak devamına neden olmaktadır. Romanların alt sınıfa sıkışmış yaşam biçimleri; yeni nesil yoksul, eğitimsiz ve dışlanmış Roman bireyleri yeniden üreten bir sürece dönüşmektedir. Bu döngünün devamı, ucuz ve geçici işgücü olarak kullanılabilen Roman işgücünü emek piyasasında devamlı hale getirmekte; özellikle küçük ve orta ölçekli işletmelerin çıkarına hizmet etmektedir. Ayrıca, sosyoekonomik ve sosyokültürel düzeyde sınırlılık, dışlanma pratikleri ile bir araya geldiğinde; etnik grubun kendi içine kapalı olma özelliğini pekiştirmekte ve grup üyelerini toplumdan daha da ayrıştırmaktadir.
Bireysel kimlik olarak Romanlık; bireyin değişen sosyoekonomik ve/veya sosyokültürel özelliklerine bağlı olarak, sosyal dışlanma korkusu nedeniyle yok sayılabilmekte veya gizlenebilmektedir. Diğer taraftan bazı bireyler, değişen sosyoekonomik ve/veya sosyokültürel özelliklerine rağmen belirli kazanımlara ulaşma amacıyla etnik kimliklerini öne çıkarmakta ve içselleştirmektedir. Dolayısıyla, birey bazında etnik kimlik, araçsal niteliğe sahiptir. Etnik kimlik, birey tarafından rasyonel olarak içselleştirilebilmekte; ya da rasyonel amaca yönelik yok sayılabilmektedir.

Kolektif kimlik olarak Romanlık, Türkiye'de 2004 yılında etnik grupların dernekleşmesine engel olan yasal engellerin kalkması ile gündeme gelmeye başlamıştır. Romanların, yurttaşl1k talebi doğrultusunda örgütlenmesi; istihdam, barınma, eğitim gibi temel sorunlarına çözüm arayışları çevresinde şekillenmektedir. Romanlığın kolektif boyutu, grubun yurttaşlık talepleri doğrultusunda tetiklenmekte; gruba ait geleneksel yaşam biçimi vurgusuyla duygusal zemin kazanmaktadır. Nitekim Roman etnik örgütlenmesine hız kazandıran dinamiklerden biri olan kentsel dönüşüm sonucu şehir merkezlerindeki bahçeli evlerinden ayrılıp apartman dairelerine yerleşmeye karşı çıkan Romanların söylemleri; etnik kimliğin kolektif boyutunun geleneksellik vurgusu zemininde duygusallık kazandığını göstermektedir. "Bir arada olma" ve "biz olma" olma duygusunun hissedilmesi, ortak hedef ve çıkarlara yönelik yoğunluk kazanmaktadır; etnik kimlik kolektif kimlik olarak da araçsal niteliğe sahiptir. 
Romanlar özelinde etnik örgütlenmenin, 2009 y1lında başbakan olan Sn. Recep Tayyip Erdoğan tarafindan başlatılan "Roman Aç1lımı" ile hız kazanması; özellikle Romanlar gibi dezavantajlı konumda yer alan etnik grupların toplumda var olma çabasında devlet politikalarının önemini vurgulamaktadır. Roman Açılımı Süreci, sosyal dışlanmanın ve ayrışmanın merkezinde olan Romanlar açısından bir dönüm noktası olmuştur. Sn. Recep Tayyip Erdoğan'ın İstanbul'da gerçekleştirdiği Roman Buluşması'nın ardından bakanlıkların, kamu kuruluşlarının ve Roman sivil toplum kuruluşlarının bir araya gelerek yürüttüğü ve bugün de yürütmekte olduğu projeler Roman yaşamını iyileştirme hedefiyle büyük adımlar atmıştır.

Roman etnik örgütlenmesi Roman Aç1lımı'ndan bu yana, özellikle birçok Roman sivil toplum kuruluşunun bir araya gelerek Türkiye Roman Dernekleri Federasyonu'nun kurmas1 ve yürüttüğü projelerle yol almış olsa da amaç birliği konusunda sorunlar yaşandığı anlaşılmaktadır. Etnik grup üyelerinin yurttaşlık bilinci açısından yerel düzeydeki eksikliklerin giderilememesi Romanlar özelinde temel sorunları ortak paydada tanımlayıp çözüm aramayı engellemektedir. Dolayısıla, sosyal devlet yurttaşlık bilincine yönelik eksik yapılanma; temel sorunların yanlış tanımlanmasına ve etnik örgütlenmenin başarısızlığına yol açabilmektedir. Dolayısıyla, bir etnik grubun örgütlenme konusunda başarı sağlayabilmesi, etnik grup üyelerinin yurttaşlık bilincinin artırılması ve bu bilinç doğrultusunda amaç birliğine varmakla mümkündür.

\section{Kaynakça}

Akgül, Başak (2010). Türkiye Çingenelerinin Politikleşmesi ve Örgütlenme Deneyimleri. Öneri $C$. 9(34): 213-222.

Alp, Hakan (2016). Çingenelere Yönelik Nefret Söyleminin Ekşi Sözlükte Yeniden Üretilmesi. İlef Dergisi 3(2): 143-172.

Barth, Frederik (1996). Ethnic Groups and Boundaries. Ethnicity (ed. John Hutchinson, Anthony D. Smith), Oxford:Oxford University Press, 75-82.

Bayraktar, Özlem (2011). Çingeneler:"Bir Başka Dünyanın İnsanları". Global Media Journal - Turkish Edition, Bahar: 118 - 132.

Çelik, Adnan ve Şahin, Emre (2012). Ötekilerin Hiyerarşisinde Kültürel ve Sınıfsal Karşılaşmalar: Kürt Toplumunda Çingene Algısı ve Sosyal Dışlanma Pratikleri. Toplum ve Kuram 6-7: 307-325.

Dişli, Semra Özlem (2016). "Çingene" mi "Roman" mı? Bir İnşa Süreci. AÜDTCF, Antropoloji Dergisi 31: 97-117.

Daşdemir, Hilmi vd. (2016). Sosyal Dışlanma Sorunsalı ve Zonguldak Roman Araştırması. Batı Karadeniz Kalkınma Ajansı: Zonguldak. http://bakkakutuphane.org/dokuman/sosyal-dislanma-sorunsalive-zonguldak-roman-arastirmasi/239, 02.02.2018'de erişildi.

Diktaş, Abdulkerim vd. (2016). Uşak'ta Yaşayan Romanların Türk Eğitim Sistemi İçerisinde Yaşadıkları Problemler. Insan ve Toplum Bilimleri Araştırmalart Dergisi 5(4): 1121-1142.

Doğan, Hülya (2016). İdeolojik Bir Kurgu ve Ötekileştirme Referansı Olarak "İnsan Doğası": Bartın Romanları Örneği. AÜDTCF, Antropoloji Dergisi 31: 141-158.

Ellner, Jack ve Coughlan, Reed (1996). The Powerty of Primordialism. Ethnicity (ed. John Hutchinson, Anthony D. Smith), Oxford: Oxford University Press, 45-51.

Erdoğan Aras, Fatma (2009). Etnik (Çingene) İşgücünün Enformel İşgücü Piyasasına Katılım Biçimleri ve Bu Süreçte Etkili Olan Faktörler: İstanbul (Cankurtaran) ve Edirne (Menzilahır) Örnekleri. Gazi Üniversitesi İktisadi ve İdari Bilimler Fakültesi Dergisi 11 / 1 75-100.

Fishman, Joshua (1996). Ethnicity as Being, Doing and Knowing. Ethnicity (ed. John Hutchinson, Anthony D. Smith), Oxford: Oxford University Press, 63-69.

Geertz, Clifford (1996). Primordial Ties. . Ethnicity (ed. John Hutchinson, Anthony D. Smith), Oxford: Oxford University Press, 40-45. 
Genç, Yusuf vd. (2015). Roman Çocuklarının Eğitim Süreci ve Akademik Başarılarında Sosyal Dışlanma Algisının Rolü. International Journal of Science 33: 79-97.

Güllüpınar, Fuat (2012). Eşitsizlik ve Toplumsal Tabakalaşma Açısından Vatandaşlık Üzerine Sosyolojik Bir Analiz. Ankara Üniversitesi SBF Dergisi 67(1): 81-109.

İlhan, Süleyman ve Fırat, Muhammet (2017). Bir İnşa Süreci Olarak Çingenelik: Kuramsal Bir Çözümleme. Firat Üniversitesi Sosyal Bilimler Dergisi 27(2): 265-276.

İlik, Bülent (2016). Türkiye'de Roman Yurttaşların Sorunları ve Çözümüne İlişkin Çalışmalar Romanların Yoğun Olarak Yaşadığı Alanlarda Sosyal İçermenin Desteklenmesi Operasyonu İçin Teknik Destek Projesi (SIROMA). http://siromatr.net/Portals/0/Act114-AnalyticReportonPolicies TR.pdf, 04.02.2018'de erişildi.

Kaleli, Lütfi (2015). Atasözleri, Deyimler, Deyişler ve Ögütler. İstanbul: Berfin.

Kemal, Ali (2005). Türk Atasözlerinden Seçmeler. İstanbul: Parıltı.

Kolukırık, Suat (2006). Sosyolojik Perspektiften Türkiye Çingeneleri: İzmir Çingeneleri Üzerine Bir Araştırma. Uluslar arası İnsan Bilimleri Dergisi 3(1): 1-24.

Kolukırık, Suat (2008). Türkiye'de Rom, Dom ve Lom Gruplarının Görünümü. Hacettepe Üniversitesi Türkiyat Araştırmaları Enstitüsü 8: 145-153.

Kolukırık, Suat (2013). Kocaeli Büyükşehir Belediyesi Romanlar ve Akraba Gruplar Taslak Eylem Planı. http://www.kocaeli.bel.tr/files/dokumanlar/kentsel_donusum/romancalistayi.pdf, 02.02.2018'de erişildi.

Koyun, Ayşe ve Çiçekoğlu, Pınar (2011). Karanlikta Kaybolan Umutlar. Anadolu Hemşirelik ve Săglık Bilimleri Dergisi 14(1): 59-65.

Marsh, Adrian (2008). Etnisite ve Kimlik. Uzpeder, Ebru vd. (Ed.), Biz Buradayı! Türkiye'de Romanlar Ayrımcı Uygulamalar ve Hak Mücadelesi (19-28). İstanbul: Mart.

Özafşar, Sabahattin (2010). Atasözleri Sözlüğü. İstanbul: İlk Adım.

Piirainen, Timo (2016). Romanların Türkiye'deki Sosyal Durumu ve Sosyal İçermenin Desteklenmesine Yönelik Kamu Politikaları Ön Çalışma, İkinci Rapor.

http://siromatr.net/Portals/0/Act111_112_2nd_Exante_study_Report_full_TR01052016.pdf, 11.11.2017'de erişildi.
Şallı, Turan (2016). Roda- Romanlar İçin Diyalog Ağ1 Gurubu Basın Açıklaması. http://www.eregder.com/?\&Syf=1\&Id=316715, 11.11.2017'de erişildi.

Taylan, Hasan Hüseyin vd. (2015). Kocaeli Romanları Üzerine Bir Araştırma. Uluslararası Roman Sorunları Çalıştayı Bildiri Kitabı, Kocaeli: 27-35.

Taylan, Hasan Hüseyin vd. (2015). Sakarya'da Romanlara Yönelik Sosyal Mesafe Araştırması. Uluslararası Roman Sorunları Çalıștayı Bildiri Kitabı, Kocaeli: 36-42 .

Uğurlu, Örgen ve Duru, Bülent (2011). Kriz ve Kentsel Yerinden Edilme Sürecinde Çingeneler. $M i$ marlar Odası Ankara Şubesi Bülteni: 71-79.

Uğurlu, Örgen (2013). Dönüşen Kentlerde Çingene Olmak: İzmit Örneği. Mülkiye Dergisi 37(1): 71104.

Uysal, Ülke (2012). Sulukule: Kentsel Dönüşüme Etno-Kültürel Bir Direniş. İdealkent 7: 136-157.

Ünaldı, Halime (2012). Türkiye'de Yaşayan Bir Kültürel Farklılık: Çingeneler. Journal of Life Sciences, 1(1): 615-626.

Weber, Max (1996). The Origins of Ethnic Groups. Ethnicity (ed. John Hutchinson, Anthony D. Smith), Oxford: Oxford University Press, 35-40.

Yanık, Celalettin (2013). Etnisite, Kimlik ve Milliyetçilik Kavramlarının Sosyolojik Analizi. Kaygı (20): 225-237.

Yağlıdere, Alper (2007). Kentsel Mekânların Kullanımında Sosyal Kategori Olarak Romanlar (Konak İlçe Belediyesi-Ege Mahallesi Örneklemi). Yayımlanmamış Yüksek Lisans Tezi. İzmir: Dokuz Eylül Üniversitesi Sosyal Bilimler Enstitüsü.

Yorulmaz, Murat (2012). Din ve Kimlik İlişkisi Bağlamında Türkiye'de Kimlik Arayışları Yapısal Bir İçerik Analizi. Electronic Journal of Political Science Studies (Elektronik Siyaset Bilimi Araştırmalart Dergisi)5: 59-74. www.ceeol.com , 11.11.2017'de erișildi.

T.C. Aile ve Sosyal Politikalar Bakanlığı Aile ve Toplum Hizmetleri Genel Müdürlüğü Roman Vatandaşlara Yönelik Strateji Belgesi 2016-2021,

http://www.aile.gov.tr/data/574ea208369dc57940f4 f523/YPK Karari.pdf, 03.02. 2018'de erişildi.

Deneklere Özgürlük (2004). http://www.radikal.com.tr/turkiye/derneklere-ozgurluk-719297/, 04.02.2018'de erişildi.

5253 Sayılı Dernekler Kanunu (2004). https://www.dernekler.gov.tr/tr/mevzuat/kanun/5253-dernekler-kanunu.aspx, $\quad$ 04.02.2018'de erişildi. 
Dokuz Sekizlik Roman Açılımı (2010). http://www.radikal.com.tr/politika/dokuz-sekizlikroman-acilimi-985693/, 07.02.2018'de erişildi.

Romanların Yoğun Olarak Yaşadıkları Yerlerde Sosyal İçermenin Desteklenmesi Operasyonu-SIROMA Projesi Sağlıkta Farkındalık Eğitimleri (2017). http://disab.saglik.gov.tr/TR,19975/romanlarin-yogun-olarak-yasadiklari-yerlerde-sosyal-icermenin-desteklenmesi-operasyonu-siroma-projesisaglikta-farkindalik-egitimleri.html, 03.02 .2018 'de erişildi.

Roman Konfederasyonu Kuruldu (2013). http://www.iha.com.tr/haber-romanlar-konfederasyonu-kuruldu-304133/, 04.02.2018'de erişildi.

Roman Veri Ăğı 100 Roman'ı İş Gücüne Katacak (2017). http://www.haberturk.com/yerel-haberler/haber/50896912-roman-veri-agi-100-romani-isgucune-katacak, 10.02 .2018 'de erişildi. 